\title{
The Relationship between the Values of Primary School and Music Teacher Candidates and Their Cheating Attitudes
}

\author{
Asuman Seda Saracaloğlu ${ }^{1}$, Ceren Saygı Gerçeker ${ }^{1} \&$ Soner Aladağ ${ }^{1}$ \\ ${ }^{1}$ Faculty of Education, Adnan Menderes University, Aydın, Turkey \\ Correspondence: Soner Aladağ, Faculty of Education, Adnan Menderes University, Aydın, Turkey. E-mail: \\ soneraladag@yahoo.com
}

Received: October 6, 2017

Accepted: November 2, 2017 Online Published: December 20, 2017

doi:10.5539/jel.v7n1p281

URL: https://doi.org/10.5539/jel.v7n1p281

\begin{abstract}
The aim of this research is to examine the relationship between the values of primary and music teacher candidates and their cheating attitudes in terms of different variables. The study group of the research is composed of 249 students who are studying at the Departments of Primary School Teaching and Music Education at Adnan Menderes University Faculty of Education. In the research, Portrait Values Questionnaire and personal information form were used. In the analysis of data, $t$ test, ANOVA, correlation analysis and tukey HSD test was used. It was detected that teacher candidates had high levels of value perceptions and the three most important values were universalism, security and self-direction. It was found that there was a statistically significant difference in primary school and music teacher candidates in all values except achievement, hedonism and stimulation according to their departments. This difference was on behalf of primary school teacher candidates. Another conclusion of the research was the gender variable. In all values except power, significant difference was on behalf of females. When the value scores of primary school and music teacher candidates were examined, all the values except for power were on behalf of freshmen. It was seen that there were significant differences between the teacher candidates' academic achievement perceptions and their value scores of achievement, stimulation, self-direction, universalism, benevolence, tradition, conformity and security except power and hedonism values. Findings related to cheating, which was another variance of the research, are as follows; cheating attitudes of primary school and music teacher candidates were moderate. It was detected that the participants had negative attitudes towards cheating. A significant difference was detected in cheating attitude according to the department. In other words, it was seen that music teacher candidates were more positive towards cheating. When cheating attitudes according to gender variable were examined, it was seen that there was a significant difference on behalf of females.
\end{abstract}

Keywords: values, cheating, teacher candidates

\section{Introduction}

The concept of value is a phenomenon that affects the emotions-thoughts-attitudes and beliefs as a whole that shape the spiritual dimension of human life. Individuals have to make decisions and implement them in various areas throughout their lives. The emotion that accompanies them while making choices and that is effective in making decisions is; values.

"Values are one of the universal problems of mankind and are the criteria that people use to make choices like good-bad, right-wrong, beautiful-ugly and determines the one that is important" (Şişman, 2000, as cited in Saracaloglu, Uca, Baydilek, \& Coşkun, 2013). Halstead \& Taylor (2000) define the concept of value as a set of principles and bases that guide behavior in terms of being good or private. In social sciences, it is not possible to speak of (to mention/ to refer) a single value definition. At this point, it will let the subject be clear to give a few definitions of value. Values are desired, guiding, post-situational goals that are different in significance. Values reflect wish preference, and desires, that is, the belief that something is desirable or not (Güngör, 1993, p. 19). Çağlar (2005) defined values as "cultural items that emerge as standards in the individuals' thoughts, attitudes and actions", whereas Erdem (2003) defined values as "the tendency to prefer a certain situation instead of the other" (cited in Ulusoy \& Dilmaç, 2015, pp. 14-15). According to Rokeach, a value "is an enduring belief that a specific mode of conduct or end-state of existence is personally or socially preferable to an opposite or converse mode of conduct or end-state of existence" $(1973$, p. 5) and a value system as a permanent organization of the 
beliefs related to the existential or preferred modes of behavior during relative importance. The characteristics of behaviors and therefore the values that guide life are as follows: affecting personal behaviors, facilitating decision-making in different choices, controlling behaviors, full of emotion, shaping behaviors, strengthening thought and understanding. So that values have a cognitive component in that an individual recognizes a correct way to behave, an emotional component in that an individual feels either positively or negatively towards a particular action and a behavioral component in that an individual will act in a certain fashion as a result of the way he or she feels (Limthanakom, Lauffer, Mujtaba, \& Murphy, Jr., 2008). In other words, values are cognitive constructs that function as criterion in selecting various behaviors to express the individual's identity (Verplanken \& Holland, 2002). Moreover, it has also an integrative power feature embraced by individuals and society (Kaltsounis, 1987; Ministry of National Education, 1987; Quisumbing \& Leo, 2005, as cited in Kasapoglu, 2013). Character education concept, which is the most popular movement today, is also dealt within the scope of values (Kirschenbaum, 2000).

Long-term researches of theorists have concentrated on the values central to understanding social behaviour (e.g., Allport, Vernon, \& Lindzey, 1960; Kluckhohn, 1951; Rokeach, 1973; Williams, 1968, as cited in Tuulik, Õunapuu, Kuimet, \& Titov, 2016). They see values as deeply rooted abstract motivations that guide, justify, and explain attitudes, norms, opinions, and actions (Rokeach, 1973; Schwartz, 1992).

Values have been classified several forms by most authors. For example; Rokeach (1973) analyzed values in two sets as terminal and instrumental values. Terminal values are divided into two parts. Personal (Self-Focused) values (happiness, inner harmony, self-respect, etc.) and social (Focus on Others) values (A World at Peace, national security, freedom, etc.). Instrumental values that are divided into two sets are moral (Focus on Morality and Relations) and competence (focus on competence) oriented (capable, logical, and intellectual) and are moral values such as honest, forgiving and responsible.

Moral values can cause feelings of regret or embarrassment when damaged. The values that Schwartz (1992, 1994) put forth at the end of his research conducted in 41 countries are: power, achievement, hedonism, stimulation, self-direction, universalism, benevolence, tradition, conformity and security.

Schwartz's Value Classification is given in Table 1.

Table 1. Schwartz's value classification

\begin{tabular}{|c|c|}
\hline Value Groups & talues \\
\hline $\begin{array}{l}\text { Social status and prestige, control or dominance over } \\
\text { and resources. }\end{array}$ & cial Power, Authority and Wealth. \\
\hline $\begin{array}{l}\text { Achievement: Personal success through demonstrating } \\
\text { competence according to social standards. }\end{array}$ & $\begin{array}{l}\text { Successful, Capable, Ambitious, Influential. being (Intelligent, } \\
\text { Self-Respect). }\end{array}$ \\
\hline Hedonism: Pleasure or sensuous gratification for oneself. & Pleasure, Enjoying Life, Self-Indulgent \\
\hline Stimulation: Excitement, novelty, and challenge in life. & Daring, a Varied Life, an Exciting Life. \\
\hline $\begin{array}{l}\text { Self-direction: Independent thought and action: choosing, } \\
\text { creating, exploring. }\end{array}$ & $\begin{array}{l}\text { Creativity, Freedom, Independent, Curious, Choosing own goals. } \\
\text { (Self-Respect) }\end{array}$ \\
\hline $\begin{array}{l}\text { Universalism: Understanding, appreciation, tolerance, and } \\
\text { protection regarding the welfare of all people and of nature. }\end{array}$ & $\begin{array}{l}\text { Broadminded, Wisdom, Social Justice, Equality, a World at Peace, a } \\
\text { World of Beauty, Unity with Nature, Protecting the Environment }\end{array}$ \\
\hline $\begin{array}{l}\text { Benevolence: Preserving and enhancing the welfare of people } \\
\text { with whom one is in frequent personal contact. }\end{array}$ & $\begin{array}{l}\text { Helpful, Honest, Forgiving, Loyal, Responsible. (True Friendship, } \\
\text { Mature Love) }\end{array}$ \\
\hline $\begin{array}{l}\text { Tradition: Respect, commitment, and acceptance of the } \\
\text { customs and ideas provided by one's culture or religion. }\end{array}$ & $\begin{array}{l}\text { Humble, Accepting my Portion in Life, Devout, Respect for Tradition, } \\
\text { Moderate }\end{array}$ \\
\hline $\begin{array}{l}\text { Conformity: Restraint of actions, inclinations, and impulses } \\
\text { likely to upset or harm others and to violate social expectations } \\
\text { or norms. }\end{array}$ & Politeness, Obedient, Self-Discipline, Honoring Parents and Elders. \\
\hline $\begin{array}{l}\text { Security: Safety, harmony, and stability of society, of } \\
\text { relationships, and of self }\end{array}$ & $\begin{array}{l}\text { Family Security, National Security, Social Order, Clean, } \\
\text { Reciprocation of Favors. (Sense of Belongings, Healty) }\end{array}$ \\
\hline
\end{tabular}

Source: Schwartz, 1996, 2012; Kuşdil \& Kağıtçıbaşı, 2000.

Many instruments were developed in order to measure values. One of them is Portrait Values Questionnaire developed by Schwartz, Melech, Lehmann, Burgress, Haris, \& Owens (2001). Schwartz et al. developed the questionnaire so as to be able to cross the limitations of Schwartz Value Questionnaire (SVQ) and measure value tendencies more effectively. Attention was drawn so that this instrument has a low concrete and cognitive burden in order for the participants with low educational levels to be able to respond easily. Besides, further attention 
was paid to develop a unique measurement tool in form and content different from Schwartz Values Questionnaire (Schwartz, 1994, p. 22; Kuşdil \& Kağıtçıbaşı, 2000; Myyry \& Helkama, 2001; Demirutku, 2007; Sığrı, Tabak \& Ercan, 2009; Yalmanc1, 2009; Demirutku \& Sumer, 2010, p. 18; Saracaloglu, Uca, Basara Baydilek, \& Coskun, 2013; Karababa, 2014)

The ten values mentioned in the Schwartz model are accepted to be universal because they are based on three basic requirements: (a) biological needs, (b) interactional requirements for interpersonal coordination, and (c) societal demands for group welfare and survival (Schwartz \& Bilsky, 1987). The three basic human requirements depend on ten universal values, and these value pursuits, depend on four basic values that are in harmony or in conflict in terms of their practical and social consequences (Morsümbül, 2014). Openness to change values (self-direction, stimulation) encourages independence of thought, feeling, and action, and receptiveness to change. They conflict with conservation values (conformity, tradition, security) that call for submissive self-restriction, preserving traditional practices, and protecting stability. Self-transcendence values (universalism, benevolence) emphasize accepting others as equals and concern for their welfare. They conflict with self-enhancement values (power, achievement) that encourage pursuing one's own relative success and dominance over others. Hedonism values share elements of both openness and self-enhancement (Schwartz, Melech, Lehmann, Burgess, Harris, \& Owens, 2001; Schwartz, 2003; Caprara, Schwartz, Capanna, Vecchione, \& Barbaranelli, 2006; Karababa, 2014; Morsümbül, 2014).

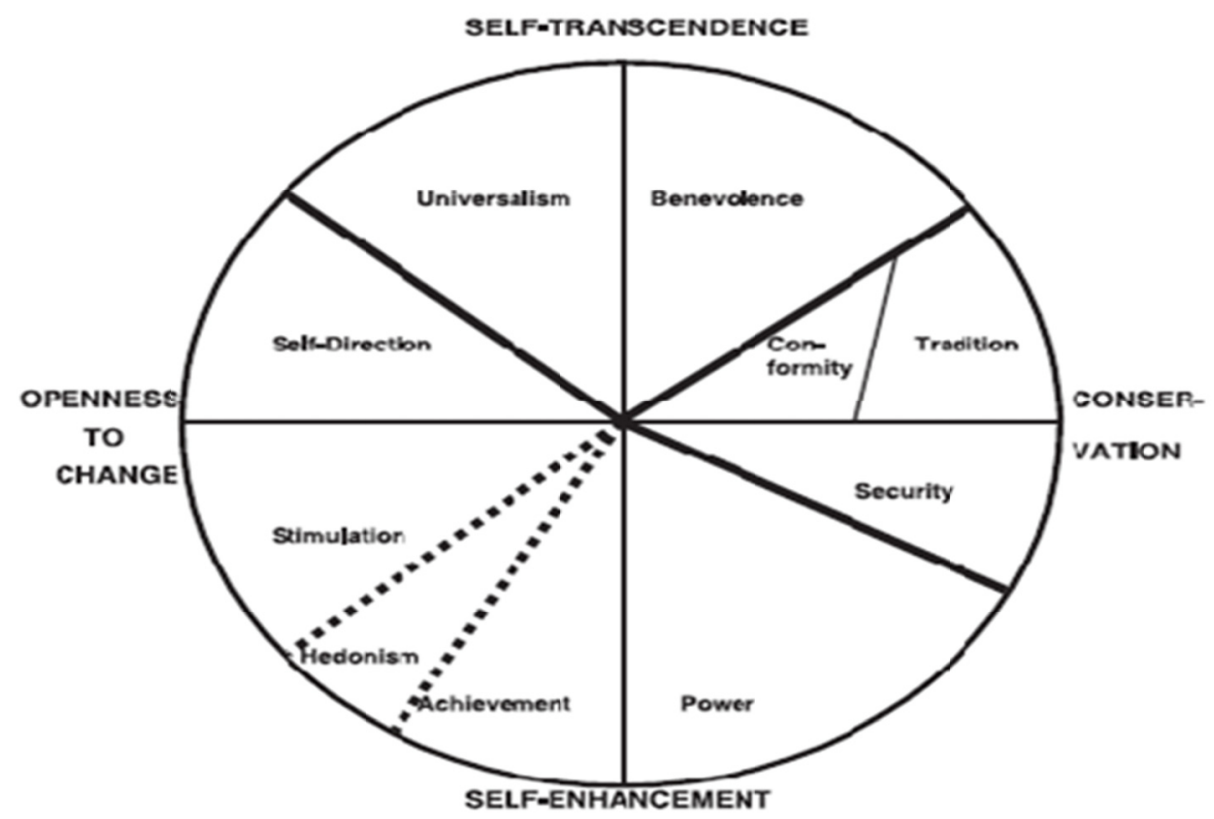

Figure 1. The motivational continuum of 10 values

The 10 values form a motivational continuum based on their pattern of compatibility and conflict. Figure 1 depicts this continuum in the form of a motivational circle. The order of the values in Table 1 follows this circle. Tests of the theory in more than 200 samples from 67 countries largely support both the content of the 10 values and the structure of relations among them (Schwartz, 1992, 1994, 2005). Studies in 37 countries around the world, were found to support the circular value model to a large extent (Schwartz, 1992; Schwartz et al., 2001). In these studies, the oppositions of self-transcendence to self-enhancement values and of openness to change to conservation values are virtually universally present. Moreover, each of the ten basic values is distinguished in at least $90 \%$ of samples. When a value is not distinguished, the items that measure it are mixed together with the items of a value that is adjacent to it in the value circle of Figure 1 (Schwartz, 2012).

More emphasis should be given on values and value education in schools and in education (Harecker, 2012). In order for values education to become part and parcel of mainstream schooling, the closest possible links need to be found between it and the world of teachers and schools (Lovat, 2005). Several researches have been carried out on values at home and abroad. 
Myyry \& Helkama (2001, p. 26) compared the values of university students $(\mathrm{N}=138)$ studying at different departments. In the research, power and achievement values of economics students, universalism value of social sciences students and security value of the students studying in technical fields were found high level.

Turan \& Aktan (2008) consisted the sample of their research of 119 teachers and 112 students and administered the Social Values Scale (SVS) developed by the researchers. According to the results of the study; the values that exist and have to exist in school life showed difference in terms of teachers and students. In the study carried out by Gürkan, Çamlıyer, \& Saracaloğlu (2000), it was aimed to determine the value system of the Physical Education and Sports teacher candidates and Rokeach Value System Scale was used. The study was conducted on a total of 336 Physical Education and Sports teacher candidates, 153 females and 183 males from three different universities. The findings of the research revealed that Physical Education and Sports teacher candidates' primary values were family security, freedom, self-respect, a world at peace and wisdom. The participants preferred the values at the lowest level were pleasure, salvation, national security, an exciting life and mature love. The most important instrumental values were honest, independent, responsible, logical and intellectual. The values of teachers were examined by Kuşdil \& Kağıtçıbaşı (2000) and it was found that the most important values were universalism, security and benevolence.

Yaman, Taflan, \& Çolak (2009) examined the values in elementary school second grade textbooks via "Values Form in Course Books". When the data of the study were analyzed, it was found that social values were mentioned the most and religious and economic values were mentioned the least in the texts. However, it was seen that in verse texts, aesthetic values and in the sixth grade textbooks, theoretical values were intensively given. Saracaloğlu, Uça, Baydilek, \& Coşkun (2013) used the Democratic Attitude Scale and the Portrait Value Questionnaire in their study carried out with 488 prospective teachers. According to the results of the research; universalism, self-direction and benevolence were the values in first three ranks, while power, achievement and tradition were in the last ranks. Besides, it was concluded that there was a significant positive relationship between the democratic attitude scores of teacher candidates and their values perception scores.

In the study conducted by the Yazar (2012), it was revealed that the main values that led the lives of the teacher candidates were spiritual values, and they were followed by economic and religious values. In the research of Oğuz (2012), it was seen that teacher candidates agreed on universalism, benevolence and security values the most. In the research conducted by Dündar (2013), it was determined that the most important value for teacher candidates was benevolence and at least important was power. Another study which aims to examine the social values that teacher candidates possess and their critical thinking levels were carried out at Adnan Menderes University $(n=488)$ and Çanakkale Onsekiz Mart University $(n=506)$ on the students studying in the Departments of Science Teaching, Social Studies, Music Education, Primary School Teaching, and Guidance and Psychological Counseling ( $\mathrm{N}=994)$. Teacher candidates' values were traditional, religious, scientific, study-work, political and family values, respectively.

The concept of value, which guides the actions of people in their daily life and explains their many behaviors, keeps an important place in education. This is concerned with the affective domain in education. According to Çetin (2006), "Teaching is a profession that requires cognitive field qualifications such as knowledge and skills. Gaining values and attitudes with regard to the profession is necessary for teacher candidates at least as knowledge".

Teachers who have one of the most important roles in the training of values also have important tasks. Teachers should be role models for their students, contribute to their moral development by giving responsibility, create learning environments where there is a common social pattern, create opportunities for sharing and collaboration, and provide decision-making opportunities (Dilmaç, 2012). Values education; creates a learning environment aiming at providing meaning by connecting values to thoughts. Moreover, it also supports the development of critical thinking and imagination, building self-awareness, and the development of internal intelligence and interpersonal skills (Tillman, 2014, p. 15). While permanent and qualified learning occurs in effective learning environments, undesirable behaviors may arise in classes where the student is passive and where he/she does feel psychologically comfortable. One of them is cheating.

Cheating is defined as "to look secretly in a source to answer questions during written exams" (Turkish Language Association, 2016). Cheating behaviors may arise due to the personal characteristics of the students (e.g., lack of self-confidence, studying with the wrong methods, unsatisfactory studying, thinking score-oriented) or the teacher's general attitudes or behaviors (e.g., giving too much importance to score, having a competitive personality, giving inadequate education) (Özgüngör, 2008). 
In fact, cheating is a serious moral and ethical problem besides being a violation of a simple rule (Selçuk, 1995). Hence, Thus, Er, \& Gürgan (2011) have stated that cheating can be described as pilferage, deception and piracy in terms of ethics and theft in terms of morality.

Besides the fact that cheating is an ethical problem, it also brings new problems at many stages of learning, from the realization of the learning event to its evaluation. (a) A clear and valid judgment cannot be reached as to whether the specified objectives have been achieved or not, it reduces the validity of the measure, (b) it is a situation that hinders learning. Because the success achieved by cheating is not a success based on the hard work and learning of the student. (c) The feeling of guilt and tension created by cheating negatively affects the psychological state of the students (Seven \& Engin, 2008).

Cheating behavior also bursts itself into sight as a greater ethical problem as time passes. In addition to transferring information from someone else or another source during exams, it has unfortunately transformed shape in various and varied ways, from doing homework for money for someone else on the websites where homework and cheating documents are shared to pilferaging project work or using someone else's homework (Bozdogan \& Öztürk, 2008). In the research conducted by Özden, Özden, \& Biçer (2015a), the academic irregularities often performed by teacher candidates focused on cheating during examinations.

Negative rhetoric such as "It is free to cheat unless being caught or something can be stolen on the condition that nobody sees it" perverts undesired behaviors like cheating. All these discourses show that cheating is closely related to ethics and morality. It is seen that this situation is related to the ethical beliefs and emotional values of the individual (Akdağ \& Güneş, 2002). Cheating also has a negative association with the individual's intrinsic control within the community (Roig \& Detommaso, 1995). Accordingly, while cheating behavior, on the one hand, prevents actual learning of the student and experiencing success, on the other hand, it causes the student to feel guilty and conflict with his intrinsic world. In addition, cheating makes it difficult to determine the actual success of the class and creates an ambiguity in this direction (Çetin, 2007).

In various researches on university students nationally and internationally, it was revealed that the participants cheated with a rate of $43 \%$ to $84 \%$ during their academic lives, albeit knowing for sure that it is wrong to cheat (Haines, Diekhoff, LaBeff, \& Clark, 1986; Davis, Grover, Becker, \& McGregor, 1992; Maramark, \& Maline, 1993; Diekhoff, LaBeff, Shinohara, \& Yasukawa, 1999; Chapman \& Weiss, 2000; Akdağ \& Güneş, 2002; Kaymakcan, 2002; Lupton \& Chapman, 2002; Smyth \& Davis, 2003; Semerci, 2004; Semerci \& Sağlam, 2005; Çetin, 2007; Bozdoğan \& Öztürk, 2008; Tayfun \& Yazıcığlu, 2008; Yangın \& Kahyaoğlu, 2009; Eraslan, 2011; Demir \& Arcagök, 2013; Soytürk, Tepeköylü Öztürk, Topuz, \& Yetim, 2015; Çeliköz, 2016).

McCabe, Butterfield, \& Trevino (2006) found in their research carried out in the United States that $56 \%$ of postgraduate students and $47 \%$ of undergraduate students were cheating. In the research conducted by Selçuk (1995) with the sample group of 200 high school students, the attitudes and opinions of the students about cheating were taken. According to the results of the research, it was conclude that male students cheated more than female students, $20 \%$ of the students never cheated before, and $28 \%$ of them cheated more than 11 times. In the research conducted by Durmuşçelebi (2011) on high school and non-thesis master's degree students, it was detected that the students perceived "cheating someone else's writing in an exam" and "using the prohibited notes in the exam" as cheating behaviors. Besides, teacher candidates constituting nearly half of the sample group stated that they exhibited cheating behavior by helping others to cheat, having someone else do their homework, and cheating from someone else consciously.

In the study conducted by Öztürk \& Yeşilyaprak (1997), it was found that students who were cheating did not regard cheating as a negative behavior and those who were cheating regarded it as a negative behavior. Semerci (2004) stated that the problem of cheating is not only a problem of institutions that educate teachers but also a problem of other faculties such as medical faculties, too. In the research conducted at Firat University Faculty of Medicine on the 5th and 6th grade students $(n=73)$, it was found that $45.2 \%$ of the participants cheated in both midterms and final exams. The students stated that they mostly cheated because they lacked confidence (64.4\%) and they mostly cheated in the multiple-choice exams. In addition, $16 \%$ of the participants did not cheat, and the most commonly used cheating method was to look at someone else's paper.

The research carried out by Semerci \& Sağlam (2005) on police vocational school students also revealed similar results in that; $40 \%$ of the participants stated that they cheated in the midterms and final exams, mostly because they lacked confidence $(66.3 \%)$ and mostly in the multiple-choice exams. The rate of those who never cheated was higher in this group (30.5\%), and the most commonly used cheating method was to look at someone else's paper. 
The frequency of students' cheating in studies conducted in Turkey and abroad was investigated depending on various variables. For example: it was found that cheating was more common among male university students than female ones; students with high academic achievement were less likely to cheat; those who had an attitude against cheating tended to cheat less than those who perceived cheating as an acceptable behavior; and while the frequency of cheating differed according to the departments of the students, it did now differ according to their grades (Tang \& Zuo, 1997; Thorpe, Pittenger, \& Reed, 1999; Yeşilyaprak \& Öztürk, 1996, as cited in Akdağ \& Güneş, 2002).

In the research conducted by Özden, Özdemir Özden, \& Baykal (2015b), it was found that the most effective reasons for teacher candidates' academic irregularities were "the intensity of the content, the wish for high grades, lack of understanding the lesson/subject and the need for assistance". The least effective reasons for teacher candidates' academic irregularities were "making friends, challenging and the desire for excitement". In the research by Orhan \& Günay (2014), it was determined that primary reasons for cheating were the fact that university students were given rote-based/non-creativity requiring assignments and that the same assignments were given every year and the assignments/projects were not read. In another research (Özden, Özdemir Özden, $\&$ Biçer, 2015a), the most common academic irregularity behaviors were "giving information to the students in the other classes after the exam about the content of the exam and allowing another student to look at the exam paper". The desire to get high grades, the intensity of the content, lack of understanding of the lesson / tutor, the need for assistance, the fear of failure and the desire to respond to family expectations, and the knowledge that everyone is doing good were the most effective reasons for teacher candidates to engage in academic irregularities.

The tendency towards cheating has been increasing at schools day by day (Schab, 1991, as cited in Anderman, Griesinder, \& Westerfield, 1998). While about $90 \%$ of students accepted that they cheated at least once until their high school graduation, many of them repeated this action more than once (Mudrock \& Anderman, 2006).

When the attitudes of teacher candidates towards cheating were examined, it was found that they were moderate in some researches (Çetin, 2007; Ünlü \& Eroğlu, 2012; Ömür, Aydın, \& Argon, 2014; Soytürk, Tepeköylü Öztürk, Topuz, \& Yetim, 2015) and low level in others (Yangın \& Kahyaoğlu, 2009). This indicated that they were inclined to cheating. In summary, as Semerci (2003) also pointed out, cheating is a problem of the educational system of every country. Accordingly, cheating can be avoided if the attitudes and behaviors of the students towards cheating can be revealed.

Within this context; it is thought that dealing with the attitudes and behaviors of teacher candidates towards cheating would be quite useful. As Soytürk et al. (2015) also emphasized, the teaching profession is a profession occupation that requires honesty, self-sacrifice and patience. It seems that the act of cheating contradicts this definition. Whatever the reason is, it can be considered that value judgements as well as teaching proficiency level of a teacher candidate who does not give an efficient level of effort in his/her education and training, who does not take ethical and moral behavior as a priority in his/her success, and who prefers to cheat instead of indigenizing the knowledge should be questioned.

In the light of all these, the aim of this research is to determine the relationship between the values of class and music teacher candidates and their cheating attitudes in terms of different variables. The sub problems of the research are given below.

\subsection{Sub Problems}

1). Do values scores of primary school and music teacher candidates differ according to departments, gender, and grades?

2). Do cheating attitudes of teacher candidates differ according to departments, gender, and grades?

3). Is there a significant relationship among teacher candidates' values and cheating attitudes and their academic score averages?

\section{Method}

\subsection{Research Model}

As the relationship between the values of teacher candidates and their cheating attitudes are analyzed, the research is a correlational design. Correlational research design is applied in estimation studies or relationship researches. Correlational researches include the studies aiming to reveal the relationships between variables using correlational statistics (Balc1, 2011). At the same time, the research is in the survey model as it examines whether the values and cheating attitudes of the teacher candidates differ according to their demographic 
variables. Survey model is a research model used to determine information types such as the attitudes, beliefs, values, habits, and thoughts of people (Mcmillan \& Schumacher, 2001).

\subsection{Study Group}

The study group consists of 249 students studying at Adnan Menderes University Faculty of Education Departments of Classroom Teaching and Music Education. $61.8 \%(n=154)$ of these students study at the Department of Classroom Teaching and 38.2\% ( $\mathrm{n}=95)$ study at the Department of Music Education. $155(62.2 \%)$ of the participants are female, $94(37.8 \%)$ of them are male, $109(43.8 \%)$ are freshman and $140(56.2 \%)$ are senior students.

\subsection{Data Collection Tools}

In the research, Portrait Values Questionnaire, Cheating Attitude Scale and personal information form composed of five questions were used.

Portrait Values Questionnaire (PVQ) was developed by Schwartz, Melech, Lehmann, Burgress, Haris and Owens in 2001 and adapted to Turkish language by Demirutku \& Sümer (2010). Portrait Values Questionnaire consists of 40 items, each of which consists of two sentences and in each item of the scale, human portraits with different value preferences are defined (Schwartz, 2004; Demirutku, 2007). Those who fill out the questionnaire are asked to identify themselves with these people and to indicate what extent they are similar with or different from themselves on the 6-point Likert-type options. The questionnaire is composed of ten individual values as (1) Power, (2) Achievement, (3) Hedonism, (4) Stimulation, (5) Self-Direction, (6) Universalism, (7) Benevolence, (8) Tradition, (9) Conformity, and (10) Security. Cronbach's alpha coefficients of the theoretical dimensions other than tradition $(\alpha=0.47)$ vary between $0.55-0.70$ (Demirutku \& Sümer, 2010). In the present research, Cronbach's alpha reliability coefficient for the whole scale was calculated as $r=.96$ and of the values, Power was found .54, Achievement .80, Hedonism .82, Stimulation .74, Self-Direction .86, Universalism .93, Benevolence .86, Tradition .74, Conformity .83, and Security .89.

In the model of Schwartz, "hedonism" value was not included in the analysis because of the fact that it was in both "Self-Enhancement" and "Openness to Change" basic values (Schwartz, 1994, p. 34).

Cheating Attitude Scale was developed by Semerci (2003) and is composed of totally 67 items, 37 of which are positive and 30 of which are negative. This scale is a scale prepared to measure the emotional part of students and can be applied starting from the second step of elementary education when students especially become conscious of cheating until postgraduate students. In the research, the scale evaluation was performed as follows: "I totally disagree: 1", "I mostly disagree: 2", "I partly agree: 3", "I mostly agree: 4" and "I totally agree: 5". In the scale, the responses of the negative items determined were recoded from "I totally agree: 1" to "I totally disagree: 5", diversely. Here, arrangements were done for the two situations encountered in attitude scales. First, positive statements were written for desired situations. Secondly, by taking negative statements for undesired situations into consideration, they were made to get equal points as positive situations. For example, "to prevent cheating is the duty of the teacher" is a desired; "cheating is dishonesty" is an undesired situation. In attitude scales, these positive and negative situations are equally scored. The low score obtained from this five-point Likert-type scale indicates the positive attitude towards cheating, whereas the high score indicates the negative attitude towards cheating. The KMO (Kaiser-Meyer-Olkin) value of the scale was calculated as 0.87 and the Bartlett test as 16059.3. As a result of factor analysis, factor loads on the scale ranged from .37 to .70 and Cronbach's alpha internal consistency coefficient was found .96 (Semerci, 2003). In the present study, Cronbach's alpha internal consistency coefficient was calculated as .94.

\subsection{Data Collection and Analysis}

In the research, it was aimed to determine whether the relationship between the values of the students and their cheating attitudes differed according to various variables. As the data was normally distributed, $t$ test, one way variance analysis and correlation analyses were performed in data analysis. Besides, when significant difference was detected, it was analyzed via Tukey HSD. In the research, SPSS 21.00 statistical package programme was used.

\section{Results}

In this section, findings and evaluation in terms of the sub problems of the research are given.

\subsection{Value Orientations of Class and Music Teacher Candidates}

Total responses that teacher candidates gave to Portrait Values Questionnaire are given in Table 2. 
Table 2. Total responses of the participants in terms of values

\begin{tabular}{llllll}
\hline & $\mathrm{N}$ & Mean & Std. Deviation & Minimum & Maximum \\
\hline Power & 249 & 3.5060 & 1.02788 & 1.00 & 6.00 \\
Achievement & 249 & 3.9006 & 1.14692 & 1.00 & 6.00 \\
Hedonism & 249 & 4.1205 & 1.36282 & 1.00 & 6.00 \\
Stimulation & 249 & 4.1258 & 1.26195 & 1.00 & 6.00 \\
Self-Direction & 249 & 4.2902 & 1.31020 & 1.25 & 6.00 \\
Universalism & 249 & 4.4250 & 1.34203 & 1.33 & 6.00 \\
Benevolence & 249 & 4.2289 & 1.27052 & 1.25 & 6.00 \\
Tradition & 249 & 3.9598 & 1.13499 & 1.00 & 6.00 \\
Conformity & 249 & 4.2189 & 1.26892 & 1.75 & 6.00 \\
Security & 249 & 4.3815 & 1.34229 & 1.20 & 6.00 \\
Valid N (listwise) & 249 & & & &
\end{tabular}

As given in Table 2, the most significant three values of teacher candidates are universalism, followed by benevolence $(\mathrm{x}=4.23)$, conformity $(\mathrm{x}=4.22)$, stimulation $(\mathrm{x}=4.13)$ and hedonism $(\mathrm{x}=4.12)$, respectively. The least significant values are power $(x=3.51)$, achievement $(x=3.90)$ and tradition $(x=3.96)$. It can be seen that the participants' value perceptions are high.

In several researches conducted using the Portrait Values Questionnaire, it was revealed that the value preferences of the teacher candidates had different significances. For example; in the research conducted by Yalmanc1 (2009), power, hedonism and stimulation had the lowest; safety, universalism and benevolence had the highest value mean scores. The most preferred values of teacher candidates in Oğuz's (2012) research were universalism, benevolence and security. In the study conducted by Dündar (2013), the most important values for teacher candidates were benevolence, security and universalism, and the least important values were power, tradition and achievement. In the study of Saracaloğlu, Uça, Başara Baydilek, \& Coşkun (2013), while universalism, self-direction (autonomy) and benevolence were the first three most important values, power, achievement and tradition were in the last raw. Kuşdil and Kağıtçıbaşı (2000) found that the most important values of teachers were universalism, security and benevolence, and least appreciated were conformity, conventionalism and power.

In the study of Yalmanc1 (2009) carried out in order to determine the value orientations of teacher candidates who were studying in the Department of Class Teaching in Zonguldak Karaelmas University, Ereğli Faculty of Education in 2008-2009 academic year; results were obtained supporting the research. Teacher candidates had the lowest arithmetic mean score of power value and the highest arithmetic mean score of safety value. Teacher candidates' value mean scores, with an order of importance, were Power, Hedonism, Achievement, Stimulation, Tradition, Self-Direction, Conformity, Benevolence, Universalism and Security, respectively. In the light of these findings, while the most significant value orientations of class teacher candidates were security, universalism and benevolence, the least valued ones were power, hedonism and achievement.

Different results were obtained in studies conducted with different value questionnaires. It was determined that the primary basic values of Physical Education teacher candidates were family security, freedom, self-esteem, and important mediator variables were honest, independent and responsible (Gürkan, Çamlıyer, \& Saracaloğlu, 2000). When these values are examined in terms of the values in Table 1, it can be seen that self-direction, benevolence and security are the primary values. In this case, it can be said that the primary values of Physical Education teacher candidates are very similar to those of the present research. In the study conducted by Yazar (2012), it was revealed that the main values that led the life of teacher candidates were spiritual values, followed by economic and religious values. In the study of Saracaloglu, Evin Gencel and Altın (2016), the student values were ranked as traditional, religious, scientific, work-business, political and family values. In both studies, it was determined that tradition value was the primary value. However, the value of tradition in the present research is the last raw. The reason for this situation may be the fact that the values are differently classified and different measurement tools are used.

The findings obtained from this research are seen to be parallel with the researches mentioned above (Gürkan, Çamlıyer, \& Saracaloğlu, 2000; Kuşdil \& Kağıtç̧ıbaşı, 2000; Yalmancı, 2009; Oğuz, 2012; Dündar, 2013; Saracaloğlu, Uça, Başara Baydilek \& Coşkun, 2013) Within this context, it can be stated that related studies support each other.

Four basic values in which the ten values mentioned above are dealt on a superior category are given in Table 3 . 
Table 3. Total responses of the participants in terms of four basic values

\begin{tabular}{llllll}
\hline & $\mathrm{N}$ & Mean & Std. Dev. & Minimum & Maximum \\
\hline Openness to Change & 249 & 4.2080 & 1.24265 & 1.25 & 6.00 \\
Conservation & 249 & 4.1867 & 1.18450 & 1.32 & 6.00 \\
Self-Enhancement & 249 & 3.7033 & .98055 & 1.00 & 6.00 \\
Self-Transcendence & 249 & 4.3270 & 1.27493 & 1.46 & 6.00 \\
Valid N (listwise) & 249 & & & & \\
\hline
\end{tabular}

As can be seen in Table 3, the four basic values of teacher candidates are Self-Transcendence $(x=4.33)$, Openness to Change $(x=4.21)$, Conservation $(x=4.19)$ and Self-Enhancement $(x=3.70)$, respectively. Accordingly, while Self-Transcendence and Openness to Change are the primary values, Self-Enhancement and Conservation are the least preferred values.

Similar findings were obtained in the research conducted by Kuşdil and Kağıtçıbaşı (2000). In their survey titled "Value Orientations of Turkish Teachers and Schwartz Value Theory", the teachers who preferred nuclear family gave more importance to Openness to Change (self-direction and stimulation) value and less importance to Conservative Approach (tradition, conformity and security) value when compared to the teachers who preferred extended family.

\subsection{Value Orientations of Class and Music Teacher Candidates-Departments}

The value scores of class and music teacher candidates are analyzed according to departments and the findings are given in Table 4.

Table 4. T test results of class and music teacher candidates' value scores according to departments

\begin{tabular}{|c|c|c|c|c|c|c|c|c|}
\hline & Department & $\mathrm{N}$ & Mean & S.s & s.h & sd & $\mathrm{t}$ & $\mathrm{p}$ \\
\hline \multirow{2}{*}{ Power } & Class & 154 & 3.5887 & .99512 & .08019 & \multirow{2}{*}{247} & \multirow{2}{*}{1.628} & \\
\hline & Music & 95 & 3.3719 & 1.07063 & .10984 & & & .106 \\
\hline \multirow{2}{*}{ Achievement } & Class & 154 & 4.0130 & 1.05981 & .08540 & \multirow{2}{*}{247} & \multirow{2}{*}{1.980} & \\
\hline & Music & 95 & 3.7184 & 1.26019 & .12929 & & & .049 \\
\hline \multirow{2}{*}{ Hedonism } & Class & 154 & 4.2511 & 1.31486 & .10595 & \multirow{2}{*}{247} & \multirow{2}{*}{1.936} & \\
\hline & Music & 95 & 3.9088 & 1.41875 & .14556 & & & .054 \\
\hline \multirow{2}{*}{ Stimulation } & Class & 154 & 4.2446 & 1.20760 & .09731 & \multirow{2}{*}{247} & \multirow{2}{*}{1.901} & \\
\hline & Music & 95 & 3.9333 & 1.32943 & .13640 & & & 0.59 \\
\hline \multirow{2}{*}{ Self-Direction } & Class & 154 & 4.4351 & 1.23960 & .09989 & \multirow{2}{*}{247} & \multirow{2}{*}{2.240} & \\
\hline & Music & 95 & 4.0553 & 1.39203 & .14282 & & & .026 \\
\hline \multirow{2}{*}{ Universalism } & Class & 154 & 4.5736 & 1.31275 & .10578 & \multirow{2}{*}{247} & \multirow{2}{*}{2.242} & \\
\hline & Music & 95 & 4.1842 & 1.36086 & .13962 & & & .026 \\
\hline \multirow{2}{*}{ Benevolence } & Class & 154 & 4.3945 & 1.25629 & .10123 & \multirow{2}{*}{247} & \multirow{2}{*}{2.651} & \\
\hline & Music & 95 & 3.9605 & 1.25389 & .12865 & & & .009 \\
\hline \multirow{2}{*}{ Tradition } & Class & 154 & 4.1153 & 1.11332 & .08971 & \multirow{2}{*}{196.870} & \multirow[b]{2}{*}{2.778} & \\
\hline & Music & 95 & 3.7079 & 1.13025 & .11596 & & & .006 \\
\hline \multirow{2}{*}{ Conformity } & Class & 154 & 4.3442 & 1.22644 & .09883 & \multirow{2}{*}{247} & \multirow{2}{*}{1.995} & \\
\hline & Music & 95 & 4.0158 & 1.31623 & .13504 & & & .047 \\
\hline \multirow{2}{*}{ Security } & Class & 154 & 4.5299 & 1.27634 & .10285 & \multirow{2}{*}{247} & \multirow{2}{*}{2.238} & \\
\hline & Music & 95 & 4.1411 & 1.41688 & .14537 & & & .026 \\
\hline
\end{tabular}

When Table 4 is analyzed, it can be seen that class and music teacher candidates value scores shows significant differences according to their departments. There are statistically significant differences in all the values except achievement, hedonism and stimulation according to departments. All the differences mentioned are on behalf of class teacher candidates.

In the research conducted by Saracaloğlu et al. (2013), it was observed that value perceptions of teacher candidates showed significant difference in "self-direction" (autonomy) and "universalism" sub dimensions according to department variable. The source of the difference in "self-direction" value was between the class teaching and science education, on behalf of science education; the source of difference in "universalism" value was between preschool education and class teaching, on behalf of preschool education, and between class teaching and science education, on behalf of science education. Myyry \& Helkama (2001, p. 26) compared the values of the university students having education in different departments $(\mathrm{N}=138)$. In the research, power and 
achievement values of the students in faculty of economics, universalism value of social sciences students and security value of the in technical fields were found high.

$\mathrm{T}$ test scores in terms of four basic values of teacher candidates according to departments are given in Table 5 .

Table 5. The distribution of the participants in terms of four basic values according to departments

\begin{tabular}{|c|c|c|c|c|c|c|c|c|}
\hline & Department & $\mathrm{N}$ & Mean & S.s & S.H & $\mathrm{t}$ & s.d & $\mathrm{p}$ \\
\hline \multirow{2}{*}{ Openness to Change } & Class & 154 & 4.3398 & 1.17605 & .09477 & \multirow{2}{*}{2.147} & \multirow{2}{*}{247} & \multirow{2}{*}{.033} \\
\hline & Music & 95 & 3.9943 & 1.32219 & .13565 & & & \\
\hline \multirow{2}{*}{ Conservation } & Class & 154 & 4.3298 & 1.14269 & .09208 & \multirow{2}{*}{3.412} & \multirow{2}{*}{289.218} & \multirow{2}{*}{.017} \\
\hline & Music & 95 & 3.9549 & 1.22004 & .12517 & & & \\
\hline \multirow{2}{*}{ Self-Enhancement } & Class & 154 & 3.8009 & .91585 & .07380 & \multirow{2}{*}{2.011} & \multirow{2}{*}{247} & \multirow{2}{*}{.045} \\
\hline & Music & 95 & 3.5452 & 1.06328 & .10909 & & & \\
\hline \multirow{2}{*}{ Self-Transcendence } & Class & 154 & 4.4840 & 1.25594 & .10121 & \multirow{2}{*}{2.494} & \multirow{2}{*}{197.374} & \multirow{2}{*}{.013} \\
\hline & Music & 95 & 4.0724 & 1.27084 & .13039 & & & \\
\hline
\end{tabular}

As can be seen in Table 5, class teacher candidates have higher scores in all the basic values than music teacher candidates.

\subsection{Value Orientations of Class and Music Teacher Candidates-Gender}

The value scores of class and music teacher candidates are analyzed according to gender and the findings are given in Table 6.

Table 6. T test results of the participants' value scores according to gender

\begin{tabular}{|c|c|c|c|c|c|c|c|c|}
\hline & Gender & $\mathrm{N}$ & Mean & S.s & s.h. & $\mathrm{t}$ & s.d & $\mathrm{p}$ \\
\hline \multirow{2}{*}{ Power } & Female & 155 & 3.5871 & .99862 & .08021 & \multirow{2}{*}{-.952} & \multirow{2}{*}{197.148} & \multirow{2}{*}{.342} \\
\hline & Male & 94 & 3.3723 & 1.06633 & .10998 & & & \\
\hline \multirow{2}{*}{ Achievement } & Female & 155 & 4.0742 & 1.09758 & .08816 & \multirow{2}{*}{-2.850} & \multirow{2}{*}{251} & \multirow{2}{*}{.005} \\
\hline & Male & 94 & 3.6144 & 1.17470 & .12116 & & & \\
\hline \multirow{2}{*}{ Hedonism } & Female & 155 & 4.3699 & 1.26990 & .10200 & \multirow{2}{*}{-3.533} & \multirow{2}{*}{251} & \multirow{2}{*}{.000} \\
\hline & Male & 94 & 3.7092 & 1.41694 & .14615 & & & \\
\hline \multirow{2}{*}{ Stimulation } & Female & 155 & 4.3097 & 1.11665 & .08969 & \multirow{2}{*}{-2.888} & \multirow{2}{*}{251} & \multirow{2}{*}{.004} \\
\hline & Male & 94 & 3.8227 & 1.42574 & .14705 & & & \\
\hline \multirow{2}{*}{ Self-Direction } & Female & 155 & 4.5161 & 1.16764 & 09379 & \multirow{2}{*}{-3.446} & \multirow{2}{*}{251} & \multirow{2}{*}{.001} \\
\hline & Male & 94 & 3.9176 & 1.44728 & .14928 & & & \\
\hline \multirow{2}{*}{ Universalism } & Female & 155 & 4.6946 & 1.23250 & .09900 & \multirow{2}{*}{4.045} & \multirow{2}{*}{251} & \multirow{2}{*}{.006} \\
\hline & Male & 94 & 3.9805 & 1.40231 & .14464 & & & \\
\hline \multirow{2}{*}{ Benevolence } & Female & 155 & 4.4726 & 1.14655 & .09209 & \multirow{2}{*}{-3.777} & \multirow{2}{*}{251} & \multirow{2}{*}{.001} \\
\hline & Male & 94 & 3.8271 & 1.36588 & .14088 & & & \\
\hline \multirow{2}{*}{ Tradition } & Female & 155 & 4.1306 & 1.06765 & .08576 & \multirow{2}{*}{-2.776} & \multirow{2}{*}{251} & \multirow{2}{*}{.006} \\
\hline & Male & 94 & 3.6782 & 1.19115 & .12286 & & & \\
\hline \multirow{2}{*}{ Conformity } & Female & 155 & 4.4403 & 1.20169 & .09652 & \multirow{2}{*}{-3.452} & 251 & 001 \\
\hline & Male & 94 & 3.8537 & 1.29847 & .13393 & & 251 & .001 \\
\hline Security & Female & 155 & 4.6310 & 1.22933 & .09874 & -3670 & 251 & 000 \\
\hline sectiony & Male & 94 & 3.9702 & 1.42390 & .14686 & -3.070 & 201 & .000 \\
\hline
\end{tabular}

When Table 6 is analyzed, it can be seen that all value scores of class and music teacher candidates except power value show significant difference according to gender, on behalf of females. Besides, albeit being statistically indifferent, the scores of females in power value are higher.

In the research by Saracaloglu et al. (2013), it was found that value perceptions of teacher candidates did not show any significant difference in power, achievement, stimulation, tradition and conformity dimensions; while their value perceptions showed significant differences in hedonism, self-direction, universalism, benevolence and security dimensions according to gender. In accordance with the results obtained, it was seen that the value perceptions of teacher candidates were significantly different in the mean scores of hedonism, self-direction, universalism, benevolence and security sub dimensions, on behalf of females. In the study of Yalmanc1 (2009), it was seen that the value types of teacher candidates were significantly different in hedonism, universalism and 
benevolence value types according to gender. This situation was on behalf of females. In other words, female classroom teacher candidates gave more importance to hedonism, universalism and benevolence values.

A survey of Finnish, Swedish and Estonian university students by Verkasalo, Daun, \& Niit (1994, as cited in Myyry \& Helkama, 2001) revealed that the primary value orientations of the students were universalism and benevolence and that females had higher scores than men. While no meaningful difference was found between Technology and Social Sciences students according to gender, it was determined that the value orientations differed among the Estonian students of economics.

In a research conducted in 47 countries using the Schwartz Values Questionnaire, it was found that males' power and achievement values were more important than females, and females values of benevolence were primarily higher than males's. This finding is consistent with the results in Finland and other Baltic countries. In all the studies, gender differences were found in power and benevolence values (Smith \& Schwartz, 1997; as cited in Kasser, 2011).

In the present research, female teacher candidates got higher scores than male teacher candidates. This situation can be interpreted as that females are more sensitive and the social expectations from females are higher today.

Table 7. The distribution of the participants in terms of four basic values according to gender

\begin{tabular}{|c|c|c|c|c|c|c|c|c|}
\hline & Gender & $\mathrm{N}$ & Mean & S.s & s.h & $\mathrm{t}$ & s.d & $\mathrm{p}$ \\
\hline \multirow{2}{*}{ Openness to Change } & Females & 155 & 4.4129 & 1.07895 & .08666 & \multirow{2}{*}{3.412} & \multirow{2}{*}{247} & \multirow{2}{*}{.001} \\
\hline & Males & 94 & 3.8701 & 1.41589 & .14604 & & & \\
\hline \multirow{2}{*}{ Conservation } & Females & 155 & 4.4006 & 1.09248 & .08775 & \multirow{2}{*}{3.754} & & \multirow{2}{*}{.000} \\
\hline & Males & 94 & 3.8340 & 1.25024 & .12895 & & 247 & \\
\hline \multirow{2}{*}{ Self-Enhancement } & Females & 155 & 3.8306 & .92429 & .07424 & \multirow{2}{*}{2.663} & & \multirow{2}{*}{.008} \\
\hline & Males & 94 & 3.4934 & 1.03813 & .10707 & & 247 & \\
\hline \multirow{2}{*}{ Self-Transcendence } & Females & 155 & 4.5836 & 1.15718 & .09295 & \multirow{2}{*}{4.214} & & \multirow{2}{*}{.000} \\
\hline & Males & 94 & 3.9038 & 1.35144 & .13939 & & 247 & \\
\hline
\end{tabular}

As can be seen in Table 7, when the basic values of Self-Transcendence, Openness to Change, Conservation and Self-Enhancement are compared in terms of gender, female teacher candidates have higher scores in all values than males. As emphasized before, this situation may stem from the fact that social roles of females and social expectations from them are higher.

\subsection{Value Orientations of Class and Music Teacher Candidates-Grades}

The value scores of class and music teacher candidates according to grades are given in Table 8 .

Table 8 . T test results of the participants' value scores according to grade

\begin{tabular}{|c|c|c|c|c|c|c|c|c|}
\hline & Grade & $\mathrm{N}$ & Mean & S.s & s.h. & $\mathrm{t}$ & s.d & $\mathrm{p}$ \\
\hline \multirow{2}{*}{ Power } & Freshmen & 109 & 3.4024 & 1.07176 & .09167 & \multirow{2}{*}{1.812} & \multirow{2}{*}{247} & \multirow{2}{*}{0.71} \\
\hline & Seniors & 140 & 3.6391 & .95703 & .09058 & & & \\
\hline \multirow{2}{*}{ Achievement } & Freshmen & 109 & 3.6893 & 1.18286 & .09989 & \multirow{2}{*}{3.363} & \multirow{2}{*}{247} & \multirow{2}{*}{.001} \\
\hline & Seniors & 140 & 4.1720 & 1.04289 & .09997 & & & \\
\hline \multirow{2}{*}{ Hedonism } & Freshmen & 109 & 3.8381 & 1.43078 & .11309 & \multirow{2}{*}{3.805} & \multirow{2}{*}{247} & \multirow{2}{*}{.000} \\
\hline & Seniors & 140 & 4.4832 & 1.18068 & .12092 & & & \\
\hline \multirow{2}{*}{ Stimulation } & Freshmen & 109 & 3.9095 & 1.38095 & .09880 & \multirow{2}{*}{3.119} & \multirow{2}{*}{247} & \multirow{2}{*}{.002} \\
\hline & Seniors & 140 & 4.4037 & 1.03147 & .11671 & & & \\
\hline \multirow{2}{*}{ Self-Direction } & Freshmen & 109 & 4.0268 & 1.42236 & .10194 & \multirow{2}{*}{3.685} & \multirow[b]{2}{*}{247} & \multirow{2}{*}{.000} \\
\hline & Seniors & 140 & 4.6284 & 1.06426 & .12021 & & & \\
\hline \multirow{2}{*}{ Universalism } & Freshmen & 109 & 4.0405 & 1.35162 & .11115 & \multirow{2}{*}{5.409} & \multirow{2}{*}{247} & \multirow{2}{*}{.000} \\
\hline & Seniors & 140 & 4.9190 & 1.16039 & .11423 & & & \\
\hline \multirow{2}{*}{ Benevolence } & Freshmen & 109 & 3.9196 & 1.33817 & .10131 & \multirow{2}{*}{4.521} & \multirow{2}{*}{247} & \multirow{2}{*}{.000} \\
\hline & Seniors & 140 & 4.6261 & 1.05772 & .11310 & & & \\
\hline \multirow{2}{*}{ Tradition } & Freshmen & 109 & 3.6125 & 1.17541 & .08688 & \multirow{2}{*}{5.825} & \multirow{2}{*}{247} & \multirow{2}{*}{.000} \\
\hline & Seniors & 140 & 4.4060 & .90701 & .09934 & & & \\
\hline \multirow{2}{*}{ Conformity } & Freshmen & 109 & 3.9089 & 1.32227 & .10328 & \multirow{2}{*}{4.537} & 247 & \\
\hline & Seniors & 140 & 4.6170 & 1.07828 & .11175 & & 241 & .000 \\
\hline Security & Freshmen & 109 & 4.0086 & 1.37477 & .10891 & 5226 & 247 & 000 \\
\hline Security & Seniors & 140 & 4.8606 & 1.13709 & .11619 & 5.220 & 241 & .000 \\
\hline
\end{tabular}


As can be seen in Table 8, all value scores except power are on behalf of senior students. In other words, achievement, hedonism, stimulation, self-direction, universalism, benevolence, tradition, conformity and security value type scores of teacher candidates differ according to their grades.

In the study of Yalmanc1 (2009), the teacher candidates having benevolence, tradition and stimulation values were on behalf of senior students. In the present research, the values mentioned are found to be on behalf of senior students. Accordingly, it can be seen that the values mentioned are paid more attention by senior students. This can be interpreted as a reflection of the education they have had.

The distribution of class and music teacher candidates' basic value scores are given in Table 9.

Table 9. The distribution of the participants in terms of four basic values according to grade

\begin{tabular}{|c|c|c|c|c|c|c|c|c|}
\hline & Grade & $\mathrm{N}$ & Mean & S.s & s.h. & $\mathrm{t}$ & s.d & $\mathrm{p}$ \\
\hline \multirow{2}{*}{ Openness to Change } & Freshmen & 109 & 3.9682 & 1.36061 & .11499 & \multirow{2}{*}{3.531} & \multirow{2}{*}{247} & \multirow{2}{*}{.000} \\
\hline & Seniors & 140 & 4.5161 & .99644 & .09544 & & & \\
\hline \multirow{2}{*}{ Conservation } & Freshmen & 109 & 3.8433 & 1.23300 & .10421 & \multirow{2}{*}{5.480} & \multirow{2}{*}{247} & \multirow{2}{*}{.000} \\
\hline & Seniors & 140 & 4.6278 & .95701 & .09167 & & & \\
\hline \multirow{2}{*}{ Self-Enhancement } & Freshmen & 109 & 3.5458 & 1.03331 & .08733 & \multirow{2}{*}{2.915} & \multirow{2}{*}{247} & \multirow{2}{*}{.004} \\
\hline & Seniors & 140 & 3.9056 & .87190 & .08351 & & & \\
\hline \multirow{2}{*}{ Self-Transcendence } & Freshmen & 109 & 3.9801 & 1.31720 & .11132 & \multirow{2}{*}{5.106} & \multirow{2}{*}{247} & \multirow{2}{*}{.000} \\
\hline & Seniors & 140 & 4.7726 & 1.06915 & .10241 & & & \\
\hline
\end{tabular}

The values attached importance differ according to grades. While the most important value is self-transcendence, the least important value is self-enhancement. However, while freshmen give priority to openness to change in the second raw, senior students find conservation value more important. In the third raw, freshmen give importance to conservation value and senior students give importance to openness to change value. Accordingly, it can be seen that the participants attached more importance to self-transcendence value rather than self-enhancement value. All basic values are on favor of senior students.

\subsection{Cheating Attitudes of Teacher Candidates}

Cheating attitudes of the participants are analyzed and the findings are given in Table 10.

Table 10. Total responses of the participants in terms of cheating attitudes

\begin{tabular}{llllll}
\hline & $\mathrm{N}$ & Mean & S.s. & Minimum & Maximum \\
\hline Cheating Total Scores & 249 & 3.0771 & .60886 & 1.18 & 4.91 \\
\hline
\end{tabular}

When cheating attitudes of the teacher candidates are analyzed, it is seen that they are at "moderate" level. Bearing in mind that low scores show positive attitude towards cheating and high scores Show negative attitude towards cheating, it can be said that the participants were negative towards cheating. In the studies by Çetin (2007), Ünlü \& Eroğlu (2012), Ömür, Aydın, \& Argon (2014), Soytürk, Tepeköylü Öztürk, Topuz, \& Yetim (2015), it was found that cheating attitude was at "moderate" level. Hence, it can be said that the studies mentioned support the present research.

\subsection{Cheating Attitudes of Teacher Candidates-Departments}

Cheating attitudes of teacher candidates according to their departments are analyzed with t-test and the findings are given in Table 11.

Table 11. T test results of the participants' cheating attitudes according to their departments

\begin{tabular}{llllllll}
\hline & Department & $\mathrm{N}$ & $\overline{\boldsymbol{X}}$ & $\mathrm{S}$ & $\mathrm{t}$ & $\mathrm{sd}$ & $\mathrm{p}$ \\
\hline \multirow{2}{*}{ Cheating Attitude } & Class & 154 & 212.578 & 41.993 & \multirow{2}{*}{3.218} & 247 & $\mathbf{. 0 0 1}$ \\
\cline { 2 - 7 } & Music & 95 & 195.768 & 36.656 & & & \\
\hline
\end{tabular}


When Table 11 is analyzed, it is seen that cheating attitudes of teacher candidates show significant difference according to their departments $\left(\mathrm{t}_{(251)}=3,067, \mathrm{p}<.05\right)$. There is a significant difference between cheating attitude mean scores of class teacher candidates $\left({ }^{\bar{x}}=211,85\right)$ and those of music teacher candidates $\left(\overline{x^{x}}=196.20\right)$. Accordingly, cheating attitudes of class teacher candidates are more negative than those of music teacher candidates. In other words, the students at the department of music education are more positive towards cheating. In the study by Ömür, Aydın, \& Argon (2014), it was also determined that cheating attitude attitudes differed according to departments. Cheating attitudes of the students at special education and fine arts departments were found to be higher. Thus, it can be thought that the findings of the present researches support each other.

\subsection{Cheating Attitudes of Teacher Candidates-Gender}

Cheating attitudes of teacher candidates according to their gender are analyzed with t-test and the findings are given in Table 12.

Table 12. T test results of the participants' cheating attitudes according to their gender

\begin{tabular}{llllllll}
\hline & Gender & $\mathrm{N}$ & $\overline{\boldsymbol{X}}$ & $\mathrm{S}$ & $\mathrm{t}$ & $\mathrm{sd}$ & $\mathrm{p}$ \\
\hline \multirow{2}{*}{ Cheating Attitudes } & Female & 155 & 211.129 & 42.602 & \multirow{2}{*}{2.492} & 247 & $\mathbf{. 0 1 3}$ \\
\cline { 2 - 7 } & Male & 94 & 197.979 & 36.380 & & & \\
\hline
\end{tabular}

When Table 12 is analyzed, it is seen that cheating attitudes of teacher candidates show significant difference according to their gender. This is on behalf of female teacher candidates. Accordingly, cheating attitudes of females are significantly higher than males. In other words, females look more negative towards cheating than men. Hence, cheating attitude in several researches were found to be on behalf of females (Akdağ \& Güneş, 2002; Çetin, 2007; Yangın \& Kahyaoğlu, 2009; Er \& Gürgan, 2011). On the other hand, it was detected in other studies that there were no significant differences according to gender. (Ünlü \& Eroğlu, 2012; Ömür, Aydın, \& Argon, 2014; Soytürk et al., 2015). These diverse findings show that more researches should be conducted in terms of gender variable.

\subsection{Cheating Attitudes of Teacher Candidates-Grades}

Cheating attitudes of teacher candidates according to their grades are analyzed with t-test and the findings are given in Table 13.

Table 13. T test results of the participants' cheating attitudes according to their grade

\begin{tabular}{|c|c|c|c|c|c|c|c|}
\hline & Grade & $\mathrm{N}$ & $\bar{X}$ & $\mathrm{~S}$ & $\mathrm{t}$ & $\mathrm{sd}$ & $\mathrm{p}$ \\
\hline \multirow{2}{*}{ Cheating Attitude } & Freshman & 109 & 207.587 & 48.389 & \multirow{2}{*}{.485} & \multirow{2}{*}{247} & \multirow{2}{*}{.628} \\
\hline & Senior & 140 & 205.057 & 33.867 & & & \\
\hline
\end{tabular}

According to t-test result in Table 12, cheating attitudes of teacher candidates does not show any significant differences according to their grades. In other words, cheating attitudes of the participants does not differ according to their grades. In the studies conducted by Ünlü \& Eroğlu (2012) and Soytürk et al. (2015), no significant differences were found. However, in the studies by Akdağ \& Güneş (2002) and Çetin (2007), there were significant differences and these differences were on behalf of senior students. In other words, it was detected that in upper grades cheating tendency was higher. Nevertheless, in the present research, as shown in Table 13, albeit being statistically indifferent, senior students' attitudes towards cheating are more negative.

\subsection{Cheating Attitudes of Teacher Candidates-The Correlation among Variables}

In order to determine whether there is a correlation among the participants' cheating attitude scores and values and academic achievement mean scores, Pearson correlation coefficients are calculated. Accordingly, positive low level relationships are detected between the participants' cheating attitude scores and the values of universalism $(\mathrm{r}=.168, \mathrm{p}<.01)$, conformity $(\mathrm{r}=.165, \mathrm{p}<.01)$, tradition $(\mathrm{r}=.163, \mathrm{p}<.01)$ and benevolence $(\mathrm{r}=.126$, $\mathrm{p}<.05)$. When evaluated in terms of basic values, positive low level relationships are detected between conservation $(\mathrm{r}=.156, \mathrm{p}<.05)$ and self-enhancement $(\mathrm{r}=.151, \mathrm{p}<.05)$. Accordingly, as cheating attitude scores 
increase, the scores in terms of the values increase, too. The point that should be emphasized here is that high scores in terms of cheating points out the negative attitude. In other words, the value scores of the students regarding cheating as negative are higher.

It is also detected that there are negative low level relationships between academic score averages and the values of tradition $(\mathrm{r}=-.261, \mathrm{p}<.01)$, universalism $(\mathrm{r}=-.213, \mathrm{p}<.01)$, security $(\mathrm{r}=-.204, \mathrm{p}<.01)$, hedonism $(\mathrm{r}=-.202, \mathrm{p}<.05)$, power $(\mathrm{r}=-.196, \mathrm{p}<.01)$, conformity $(\mathrm{r}=-.183, \mathrm{p}<.05)$, benevolence $(\mathrm{r}=-.174, \mathrm{p}<.05)$ and self-direction $(\mathrm{r}=-.165$, $\mathrm{p}<.05$ ). When the relationships between basic values and academic achievement are evaluated, negative low level relationships are calculated among the basic values of conservation $(\mathrm{r}=.228, \mathrm{p}<.01)$, self-transcendence $(\mathrm{r}=-.199, \mathrm{p}<.01)$, self-enhancement $(\mathrm{r}=-.177, \mathrm{p}<.05)$ and openness to change $(\mathrm{r}=-.161, \mathrm{p}<.05)$. Accordingly, as academic score averages decrease, the value scores of teacher candidates increase. An evaluation to what this finding stems from cannot be made. This finding is thought to be extremely remarkable and it should be investigated deeply.

\section{Discussion}

It is detected that the participants' value perceptions are high. The most significant three values of teacher candidates are universalism, reliability and self-direction. These are followed by benevolence, conformity, stimulation and hedonism, respectively. The least significant values are power, achievement and tradition. Moreover, the four basic values of teacher candidates are self-transcendence, openness to change, conservation and self-enhancement, respectively. Accordingly, while self-transcendence and openness to change are the primary values, self-enhancement and conservation are less preferred values.

It is found that class and music teacher candidates value scores shows significant differences according to their departments. There are statistically significant differences in all the values except achievement, hedonism and stimulation according to departments. Class teacher candidates have higher scores in all values when compared to music teacher candidates.

It is found that all value scores of class and music teacher candidates except power value show significant difference according to gender, on behalf of females. Besides, albeit being statistically indifferent, the scores of females in power value are higher. When the basic values of self-transcendence, openness to change, conservation and self-enhancement are compared in terms of gender, again, female teacher candidates have higher scores in all values than men.

All value scores of the teacher candidates except power are on behalf of senior students. The values attached importance differ according to grades. While the most important value is self-transcendence in both sides, the least important value is self-enhancement. However, the values that freshmen and senior students give priority in the second and third raw differ. Accordingly, it can be seen that the participants attached more importance to self-transcendence value rather than self-enhancement value. All basic values are on behalf of senior students.

It is found that the value scores of teacher candidates in achievement, stimulation, self-direction, universalism, benevolence, tradition, conformity and security values except power and hedonism show significant difference according to academic achievement perceptions. This difference is on behalf of the ones with "good" academic achievement perceptions.

Cheating attitude scores of teacher candidates are at "moderate" level. It is detected that the participants look cheating negatively. When cheating attitude scores are analyzed according to departments, it is realized that there is a significant difference. In other words, the students at the department of music education regard cheating more positively. Cheating attitude scores of the participants according to their gender, which is another variable of the research, are detected to be significantly different, on behalf of females. In other words, female teacher candidates regard cheating negatively. Cheating attitude scores of teacher candidates does not show any significant differences according to their grades and academic achievement perceptions. In other words, cheating attitude is independent from their grade levels and academic achievement perceptions.

It is detected that there are positive low level relationships between teacher candidates' cheating attitudes and their values. Accordingly, as cheating attitude scores increase, the scores in terms of the values increase, too. As mentioned before, high scores in terms of cheating points out the negative attitude. In other words, the value scores of the students regarding cheating as negative are higher.

Besides, it is also detected that there are negative low level relationships between academic score averages of the participants and their value scores. Accordingly, as academic score averages decrease, the value scores of teacher candidates increase. An evaluation to what this finding stems from cannot be made. This finding is thought to be extremely remarkable and it should be investigated deeply. 
In the light of the research findings, the following suggestions are developed.

1). Within the scope of values education that bears upon the emotional part of education; it can be effective to put more emphasis on acquiring the values related to professional ethics, achievement and self-improvement in order to reduce cheating incidents.

2). Creating classroom and school environments that are far from having high-scores from the exams, being competitors and having an understanding of exam-based culture can reduce cheating incidents.

3). Before the exams, such environments as unlocking the classes just before the start of the exams, allowing the students in the exams after checking their identity cards, and not allowing the students in the exams with their mobile phones and with other electronic devices.

4). It is considered necessary for the staff in the examinations to be conscious and supported about the methods of cheating and the necessary measures.

5). The creation of more democratic class environments in Turkey, as in the world, can reduce cheating incidents.

6). Teacher candidates should be made more competent in assessment and evaluation in education and they should be made to do more practical works.

7). Teacher candidates should be encouraged to become more conscious of the learning strategies and effective studying techniques and to improve themselves, especially during the orientation period and in the first years of their professional life. Thus, cheating can be prevented.

8). Guidance and psychological counseling units of the universities may conduct seminars or group therapies on test anxiety.

\section{References}

Akdağ, M., \& Güneş, H. (2002). Kopya Çekme Davranışları ve Kopya Çekmeye İlişkin Tutumlar. Kuram ve Uygulamada Ĕ̈itim Yönetimi, 8(3), 330-343.

Anderman, E. M., Griesinger, T., \& ve Westerfield, G. (1998). Motivation And Cheating During Early Adolescence. Journal of Educational Psychology, 90(1), 84-93. https://doi.org/10.1037/0022-0663.90.1.84

Asan, T., Ekşi, F., Doğan, A., Ekşi, H. (2008). Unpublished paper. Retrieved from http://dspace.marmara.edu.tr/handle/18832014/1179

Bektaş, F., \& Nalçacı, A. (2012). Bireysel Değerler ve Öğretmenlik Mesleğine Yönelik Tutum Arasındaki İlişki, Kuram ve Uygulamada Eğitim Bilimleri, 1239-1248.

Bozdoğan, A. E., \& Öztürk, Ç. (2008). Öğretmen Adayları Neden Kopya Çeker? İlköğretim Online, 7(1), 141-149.

Caprara, G. V., Schwartz, S., Capanna, C., Vecchione, M., \& Barbaranelli, C. (2006). Personality and Politics: Values, Traits, and Political Choice. Political Psychology, 27(1), 1-28. https://doi.org/10.1111/j.1467-9221.2006.00447.x

Çetin, Ş. (2006) Öğretmenlik Mesleği Tutum Ölçeğinin Geliştirilmesi (Geçerlik ve Güvenirlik Çalışması). Gazi Üniversitesi Endüstriyel Sanatlar Eğitim Fakültesi Dergisi, 18, 28-37.

Çetin, Ş. (2007). Üniversite öğrencilerinin kopya çekme davranışlarının farklı değişkenler açısından incelenmesi. Milli Eğitim, 175, 129-142.

Davis, S. F., Grover, C. A., Becker, A. H., \& McGregor, L. N. (1992). Academic dishonesty: Prevalence, determinants, techniques, and punishments. Teaching of Psychology, 19(1), 16-20. https://doi.org/10.1207/s15328023top1901_3

Demir, M. K., \& ve Arcagök, S. (2013). Sınıf Öğretmeni Adaylarının Sınavlarda Kopya Çekilmesine İlişkin Görüşlerinin Değerlendirilmesi. Erzincan Üniversitesi Eğitim Fakültesi Dergisi, 15(1), 148-165.

Demirutku, K. (2007). Parenting styles, internalization of values, and the self-concept. Doctoral Dissertation, Middle East Technical University, Ankara.

Demirutku, K. ve Sümer, N. (2010). Temel Değerlerin Ölçümü: Portre Değerler Anketi’nin Türkçe Uyarlaması, Türk Psikoloji Yazllarl, 13(25), 17-25.

Diekhoff, G. M., LaBeff, E. E., Shinohara, K., \& Yasukawa, H. (1999). College cheating in Japan and the United States. Research in Higher Education, 40(3), 343-353. https://doi.org/10.1023/A:1018703217828 
Dilmaç, B. (2012). İnsanca Değerler Eğitimi. Pegem Akademi, Ankara.

Dilmaç, B., \& ve Bircan, H. H. (2014). Değerler ve Değerler Psikolojisi. Pegem Akademi, Ankara.

Durmuşçelebi, M. (2011). Lise Öğrencilerinin ve Öğretmen Adaylarının Kopya Çekme Davranışlarına İlişkin Görüşleri. Kuram ve Uygulamada Eğitim Yönetimi, 17(1), 77-97.

Dündar, H. (2013). Öğretmen adaylarının sahip olduğu değerler ile demokratik tutumları arasındaki ilişki. The Journal of Academic Social Science Studies, 6(2), 367-381.

Er, K. O., \& ve Gürgan, U. (2011). Öğretmen Adaylarının Öz-Yeterlilik Algıları ve Kopya Çekmeye İlişkin Tutumları Arasındaki İlişki. Ballkesir Üniversitesi Sosyal Bilimler Enstitüsü Dergisi, 14(26), 1-18.

Eraslan, A. (2011). Matematik öğretmeni adayları ve kopya: Hiç çekmedim desem yalan olur! Eğitim ve Bilim, 36(160), 52-64.

Fırat, N. Ş., \& Açıkgöz, K. (2012). Bazı Değişkenler Açısından Öğretmenlerin Değer Sistemleri, Hacettepe Üniversitesi Eğitim Fakültesi Dergisi, 43, 422-435.

Gürkan, H., Çamlıyer, H., \& ve Saracaloğlu, A. S. (2000). Beden Eğitimi Öğretmeni Adaylarının Değerler Sistemi. G. U. Beden Ĕgitimi ve Spor Bilimleri Dergisi, V(1), 35-52.

Haines, V. J., Diekhoff, G. M., LaBeff, E. E., \& ve Clark, R. E. (1986). College Cheating: Immaturity, Lack of Commitment, and the Neutralizing Attitude. Research in Higher Education, 25(4), 342-354. https://doi.org/10.1007/BF00992130

Halstead, J. M., \& ve Taylor, M. J. (2000) Learning and Teaching about Values: A review of recent research. Cambridge Journal of Education, 30(2), 169-202. https://doi.org/10.1080/713657146

Harecker, G. (2012). Teaching Values at School: A Way to Reach a Better Understanding in our World, in Conference Proceedings. New perspectives in Science Education. Florence, Italy: Pixel, University Press.

İmamoğlu, E. O., \& ve Karakitapoğlu Aygün, Z. (1999). 1970’lerden 1990’lara Değerler: Üniversite Düzeyinde Gözlenen Zaman, Kuşak ve Cinsiyet Farklılıkları. Türk Psikoloji Dergisi, 14(44), 1-22.

Karababa. (2014). Değerler ve Değerler Psikolojisi. B. Dilmaç \& H. H. Birca (Eds.). Ankara.

Kasapoğlu, H. (2013). Okulda Değer Eğitimi ve Hikâyeler, Milli Eğitim Üç Ayllk Eğitim ve Sosyal Bilimler Dergisi, 42(198), 97-108.

Kasser, T. (2011). Cultural Values and the Well-Being of Future Generations: A Cross-National Study. Journal of Cross-Cultural Psychology, 42(2), 206-215. https://doi.org/10.1177/0022022110396865

Kirschenbaum, H. (2000). From Values Clarification to Character Education: A Personal Journey. Journal of Humanistic Counseling, Education \& Development, $39(1), \quad 4-20$. https://doi.org/10.1002/j.2164-490X.2000.tb00088.x

Kuşdil, E., \& ve Kağıtçıbaşı, Ç. (2000). Türk Öğretmenlerin Değer Yönelimleri ve Schwartz Değer Kuramı. Türk Psikoloji Dergisi, 15(45), 59-76.

Limthanakom, N., Lauffer, W., Mujtaba, B. G., \& Murphy, Jr., E. F. (2008). The Ranking of Terminal and Instrumental Values by Working Professionals in Thailand, Singapore and The United States: What Is Important and How Do They Impact Decision-Making? International Business \& Economics Research Journal, 7(4), 45-60.

Lovat, T. (2005). Values Education and Teachers' Work: A Quality Teaching Perspective. New Horizons in Education, 112.

Lupton, R. A., \& Chapman, K. J. (2002). Russian and American college students' attitudes, perceptions and tendencies towards cheating. Educational Research, 44(1), 17-27. https://doi.org/10.1080/00131880110081080

Lupton, R. A., Chapman, K. J., \& Weiss, J. E. (2000). International perspective: A cross-national exploration of business students' attitudes, perceptions, and tendencies toward academic dishonesty. Journal of Education for Business, 75(4), 231-235. https://doi.org/10.1080/08832320009599020

McCabe, D. L., Butterfield, K. D., \& Trevino, L. K. (2006). Academic dishonesty in graduate business programs: Prevalence, causes, and proposed action. Academy of Management Learning \& Education, 5(3), 294-305. https://doi.org/10.5465/AMLE.2006.22697018 
Mcmillan, J. H., \& Schumacher, S. (2001). Research in education. A conceptual introduction (5th edition). New York: Addison Wesley Longman Inc.

Morsümbül, Ş. (2014). Değerlerin Kuşaklar Arası Değişimi: Ankara Örneği. Yayınlanmamış Doktora Tezi. Hacettepe Üniversitesi Sosyal Bilimler Enstitüsü, Ankara.

Murdock, T. B., \& ve Anderman, E. M. (2006). Motivational Perspectives on Student Cheating: Toward an Integrated Model of Academic Dishonesty. Educational Psychologist, 41(3), 129-145. https://doi.org/10.1207/s15326985ep4103_1

Oğuz, E. (2012). Öğretmen adaylarının değerler ve değerler eğitimine ilişkin görüşleri. Kuram ve Uygulamada Ĕgitim Bilimleri, 12(2), 1309-1325.

Orhan, F., \& ve Günay, A. (2014). Üniversite öğrencilerinin internet tabanlı akademik usulsüzlük nedenlerinin çeşitli değişkenlere göre incelenmesi. Ege Eğitim Dergisi, 15(1), 176-190. https://doi.org/10.12984/eed.41835

Özden, M., Özdemir Özden, D., \& ve Biçer, B. (2015). Akademik Usulsüzlük: Öğretmen Adaylarının Görüşleri ve Deneyimleri. Mersin Üniversitesi Eğitim Fakültesi Dergisi, 11(2), 505-525. https://doi.org/10.17860/efd.43453

Özden, M., Özdemir Özden, D., \& ve Biçer, B. (2015). Akademik Usulsüzlük: Sınıf Öğretmeni Adaylarının Deneyimleri. Dumlupinar Üniversitesi Sosyal Bilimler Dergisi, 45, 130-143.

Özgüngör, S. (2008). Üniversite Öğrencilerinde Öğretmene İlişkin Algıların ve Öğrenci Özelliklerinin Kopya Çekme Davranışlarıyla İlişkisi, Eğitim ve Bilim, 33(149).

Roig, M., \& ve Detommaso, L. (1995). Are College Cheating and Plagiarism Related to Academic Procrastination? Psychological Reports, 77, 691-698. https://doi.org/10.2466/pr0.1995.77.2.691

Rokeach, M. (1973). The nature of human values. New York, NY: Free Press.

Sağnak, M. (2005). İlköğretim Okullarında Görevli Yönetici ve Öğretmenlerin Örgütsel Değerlere İlişkin Algiları. Eğitim ve Bilim, 30(135), 50-50.

Saracaloğlu, A. S, Uça, S., Baydilek, N. B., \& Coşkun, N. (2013). Öğretmen Adaylarının Demokratik Tutumları ile Değer Algılarının İncelenmesi, Adnan Menderes Üniversitesi Eğitim Fakültesi Ĕgitim Bilimleri Dergisi, Haziran, 4(1), 45-59.

Saracaloğlu, A. S., Evin Gencel, İ., \& ve Altın, M. (2016). Öğretmen Adaylarının Sahip Olduğu Sosyal Değerler İle Eleştirel Düşünme Düzeylerinin İncelenmesi. Ankara: Atatürk Kültür, Dil ve Tarih Yüksek Kurumu, Atatürk Araştırma Merkezi. Cilt I, 441-465.

Schwartz, S. H. (1992). Universals in the content and structure of values: Theoretical advances and empirical tests in 20 countries. Advances in Experimental Social Psychology, 25, 1-65. https://doi.org/10.1016/S0065-2601(08)60281-6

Schwartz, S. H. (1994). Are the Universal Aspects in the Structure and Content of Human Values. Journal for Social Issues, 50(4), 19-45. https://doi.org/10.1111/j.1540-4560.1994.tb01196.x

Schwartz, S. H. (1996). Value priorities and behavior: Applying a theory of integrated value systems. In C. Seligman, J. M. Olson, \& M. P. Zanna (Eds.), The psychology of values: The Ontario symposium (Vol. 8., pp. 1-24). Hillsdale, NJ: Lawrence Erlbaum.

Schwartz, S. H. (1999). A theory of cultural values and some implications for work. Applied Psychology: An International Review, 48, 23-47. https://doi.org/10.1111/j.1464-0597.1999.tb00047.x

Schwartz, S. H. (2012). An Overview of the Schwartz Theory of Basic Values. Online Readings in Psychology and Culture, 2(1). http://dx.doi.org/10.9707/2307-0919.1116

Schwartz, S. H. and Bilsky, W. (1987). Toward a Universal Psychological Structure of Human Values. Journal of Personality and Social Psychology, 53(3), 550-562. https://doi.org/10.1037/0022-3514.53.3.550

Schwartz, S. H., Melech, G., Lehmann, A., Burgess, S., Harris, M., \& Owens,V. (2001). Extending the Cross-Cultural Validity of the Theory of Basic Human Values with a Different Method of Measurement. Journal of Cross-Cultural Psychology, 32(5), 519-542. https://doi.org/10.1177/0022022101032005001

Selçuk, Z. (1995). Bir Eğitim ve Rehberlik Sorunu: Okullarda Kopya Çekme, Eğitim Yönetimi, 1(3). 
Semerci, Ç. (2004). Tıp Fakültesi Öğrencilerinin Kopya Çekmeye Yönelik Tutum ve Görüşleri. Fırat Üniversitesi Sağllk Bilimleri Dergisi, 18(3), 139-146.

Semerci, Ç., \& ve Sağlam Z. (2005). Polis Adaylarının Sınavlarda Kopya Çekmeye İlişkin Tutum ve Görüşleri (Elazı ̆̆ İli Örneği). Fırat Üniversitesi Sosyal Bilimler Dergisi, 15(2), 163-177.

Semerci, Ç. (2003). Kopya Çekmeye İlişkin Tutum Ölçeği. Fırat Üniversitesi Sosyal Bilimler Enstitüsü Dergisi, 13(1), 227-234.

Seven, M. A., \& ve Engin, A. O. (2008). Eğitim Fakültesi Öğrencilerinin Kopya Çekmeye Duydukları İhtiyaç ve Kopya Çekme Sebepleri. Atatürk Üniversitesi Sosyal Bilimler Enstitüsü Dergisi, 1, 121-136.

Sığrı, Ü., Tabak, A., \& ve Ercan, Ü. (2009). Kültürel değerlerin yönetsel kapsamda analizi: Türk bankacılık sektörü uygulaması. Organizasyon ve Yönetim Bilimleri Dergisi, 1(2), 1-14.

Soytürk, M., Tepeköylü Öztürk, Ö., Topuz, E. ve Yetim, H. (2015). Beden Eğitimi Öğretmen Adaylarının Benlik Saygıları ile Kopya Çekmeye İlişkin Tutumları Arasındaki İlişkinin İncelenmesi (CBÜ, BESYO örneği). Uluslararast Spor, Egzersiz ve Antrenman Bilimi Dergisi, 1(1), 20-30

Tayfun, A., \& ve Yazıcıŏlu, İ. (2008). Öğrencilerin kopya hakkındaki görüşleri üzerine bir araştırma. Türk Eğitim Bilimleri Dergisi, 6, 375-393.

Telef, B. B., Uzman, E., \& Ergün, E. (2013). Öğretmen Adaylarında Psikolojik İyi Oluş ve Değerler Arasındaki İlişkinin İncelenmesi. Turkish Studies, 8(12), 1297-1307. https://doi.org/10.7827/TurkishStudies.5699

Tilmann, D. (2014). 4-14 Yaş Grubu Öğrencileri İ̧̧in Yaşayan Değerler Eğitimi Etkinlikleri (Ed. Vedat Aktepe), Eğitim Yayınevi, Konya.

Turan, S., \& ve Aktan, D. (2008). Okul Hayatında Var Olan ve Olması Gereken Sosyal Değerler, Türk Eğitim Bilimleri Dergisi, 6(2), 227-259.

Turkish Language Association (2016). http://www.tdk.gov.tr/index.php?option=com_gts\&arama=gts\&guid=TDK.GTS.576928444e6c68.2000606 8

Ulusoy, K., \& Dilmaç, B. (2015). Değerler Eğitimi. Pegem Akademi, Ankara.

Ünlü, H., \& ve Eroğlu, C. (2012). Beden eğitimi öğretmen adaylarının kopya çekmeye yönelik tutumları. Spormetre: Beden Eğitimi ve Spor Bilimleri Dergisi, (3), 101-106.

Verplanken, B., \& Holland, R. W. (2002). Motivated decision making: Effects of activation and self-centrality of values on choices and behavior. Journal of Personality and Social Psychology, 82(3), 434-447. http://dx.doi.org/10.1037/0022-3514.82.3.434

Yalmancı, S. (2009). Öğretmen adaylarının değer yönelimlerinin çeşitli değişkenler açısından incelenmesi. Yüksek Lisans Tezi, Zonguldak Karaelmas Üniversitesi, Zonguldak.

Yaman, H., Taflan, S., \& Çolak, S. (2009). İlköğretim İkinci Kademe Türkçe Ders Kitaplarında Yer Alan Değerler, Değerler Ĕgitimi Dergisi, 7(18), 107-120.

Yangın, S., \& ve Kahyaoğlu, M. (2009). İlköğretim öğretmen adaylarının kopya çekmeye yönelik tutum ve görüşleri. Balıkesir Üniversitesi Sosyal Bilimler Enstitüsü Dergisi, 12(21), 46-55.

Yazar, T. (2012). Öğretmen Adaylarının Değerler Hakkındaki Görüşleri. Pegem Eğitim ve Öğretim Dergisi, 2(1), 61-68. https://doi.org/10.14527/C2S1M6

\section{Copyrights}

Copyright for this article is retained by the author(s), with first publication rights granted to the journal.

This is an open-access article distributed under the terms and conditions of the Creative Commons Attribution license (http://creativecommons.org/licenses/by/4.0/). 